\title{
A mean net accumulation pattern derived from radioactive layers and radar soundings on Austfonna, Nordaustlandet, Svalbard
}

\author{
Jean Francis Pinglot, ${ }^{1}$ Jon Ove Hagen, ${ }^{2}$ KJetil Melvold, ${ }^{2}$ Trond Eiken, ${ }^{2}$ Christian Vincent ${ }^{1}$ \\ ${ }^{1}$ Laboratoire de Glaciologie et Géophysique de l'Environnement du CNRS, 54 rue Molière, BP 96, 38402 Saint-Martin-d'Hères Cedex, France \\ ${ }^{2}$ Department of Geography, University of Oslo, P.O. Box 1042, Blindern, N-0316 Oslo, Norway
}

\begin{abstract}
We present the snow-accumulation distribution over Austfonna, Nordaustlandet, Svalbard, based on 29 shallow ice cores that were retrieved from this ice cap during 1998 and 1999. Mean annual net accumulation is deduced from radioactive layers resulting from the 1954-74 atmospheric nuclear tests (maximum in 1963) and the Chernobyl accident (1986). The Chernobyl layer was located in 19 ice cores in the accumulation area, and the nuclear test layer was located in two deeper ice cores. In addition, the spatial variation of the depth of winter 1998/99 snowpack was mapped using snow probing, groundpenetrating radar methods and pit studies. The altitudinal gradient of the mean annual net mass balance and the altitude of the mean equilibrium line are determined along five transects ending at the top of the ice cap. The mean annual net mass balance and the equilibrium-line altitudes show a high degree of asymmetry between the western and eastern parts of Austfonna, in accordance with the distribution of winter accumulation. Large interannual variations of the accumulation exist. However, the study of the mean annual net mass balance shows no trend for two different time periods, 1963-86 and 1986 to the date of the drillings (1998/99).
\end{abstract}

\section{INTRODUGTION}

Austfonna $\left(79-80^{\circ} \mathrm{N}, 20-27^{\circ} \mathrm{E}\right)$, an ice cap on Nordaustlandet, Svalbard, has an area of $8120 \mathrm{~km}^{2}$, a maximum altitude of $783 \mathrm{~m}$ and a maximum ice thickness of about $560 \mathrm{~m}$ (Dowdeswell and others, 1986) (Fig. 1). The ice cap is divided into a number of drainage basins which appear to be characterized by diverse flow regimes (Dowdeswell, 1986). Svalbard is at the northern extremity of the warm North Atlantic drift. As a result, the archipelago is particularly sensitive to climate shifts associated with changes in the North Atlantic drift.

A number of glaciological investigations have been conducted on Austfonna. Traverses across the ice cap were carried out by A.E. Nordenskjold in 1873, the Oxford expedition in 1924 (Binney, 1925), H.W:son Alhmann in 1931 (Ahlmann, 1933), V. Schytt in 1957 and 1958 (Schytt, 1964) and J. A. Dowdeswell in 1983, 1986 and 1987 (Dowdeswell and Drewry, 1989). Deep ice cores were obtained by Soviet teams at Vestfonna in 1981 and Austfonna in 1985 and 1987 (Punning and others, 1986; Zagorodnov and Arkhipov, 1990) and by Japanese scientists (National Institute of Polar Research (NIPR)) at Vestfonna in 1995 and Austfonna in 1998 and 1999 (Watanabe and others, 2000).

Data on snow-accumulation distribution are a prerequisite to sensitivity modelling of ice caps by means of energybalance models (Fleming and others, 1997). Little is known of the present mass balance of Austfonna, and field investigations were necessary to obtain data on snow accumulation and the net accumulation pattern. This paper presents results of these recent field investigations on Austfonna. The aim of this work is to determine (a) the 1997/98 and 1998/99 winter accumulations and mean annual net mass-balance patterns over the ice cap, (b) the mean equilibrium-line altitude (ELA), (c) the mass budget of the Austfonna accumulation area and (d) natural and artificial radioactive deposition over the Austfonna accumulation area.

\section{DATA SOURGES AND METHODS}

\subsection{Ice-core data}

During two field seasons on Austfonna in April 1998 and April-May 1999, eight and twenty-one shallow ice cores, respectively, were drilled in the accumulation area and in the upper part of the ablation area of Austfonna (Fig. 1; Table 1) (Melvold and others, 1999). The cores were retrieved with a Polar Ice Coring Office (PICO) lightweight auger for shallow depths down to about $15 \mathrm{~m}$. The drill produced cores with a $77 \mathrm{~mm}$ diameter and a mean length of about $40 \mathrm{~cm}$. In addition, two deeper ice cores were drilled in 1998 and 1999 by the NIPR (K. Kamiyama and others, unpublished information). These cores were drilled with an electromechanical drill down to 118 and $288 \mathrm{~m}$, respectively.

The snow and firn densities were determined immediately after the retrieval of the ice cores by measuring the diameter, length and weight of each core section. Figure 2 shows density profiles along cores $\mathrm{X}, \mathrm{E}, \mathrm{G}, \mathrm{N}$ and T. While the density increases semi-continuously for cores $\mathrm{X}$ and $\mathrm{E}$, it increases abruptly at depths of about $2 \mathrm{~m}$, under the winter snow layer for ice cores G, N and T. The density of the 1998/ 99 winter snow cover was found by averaging the density of 


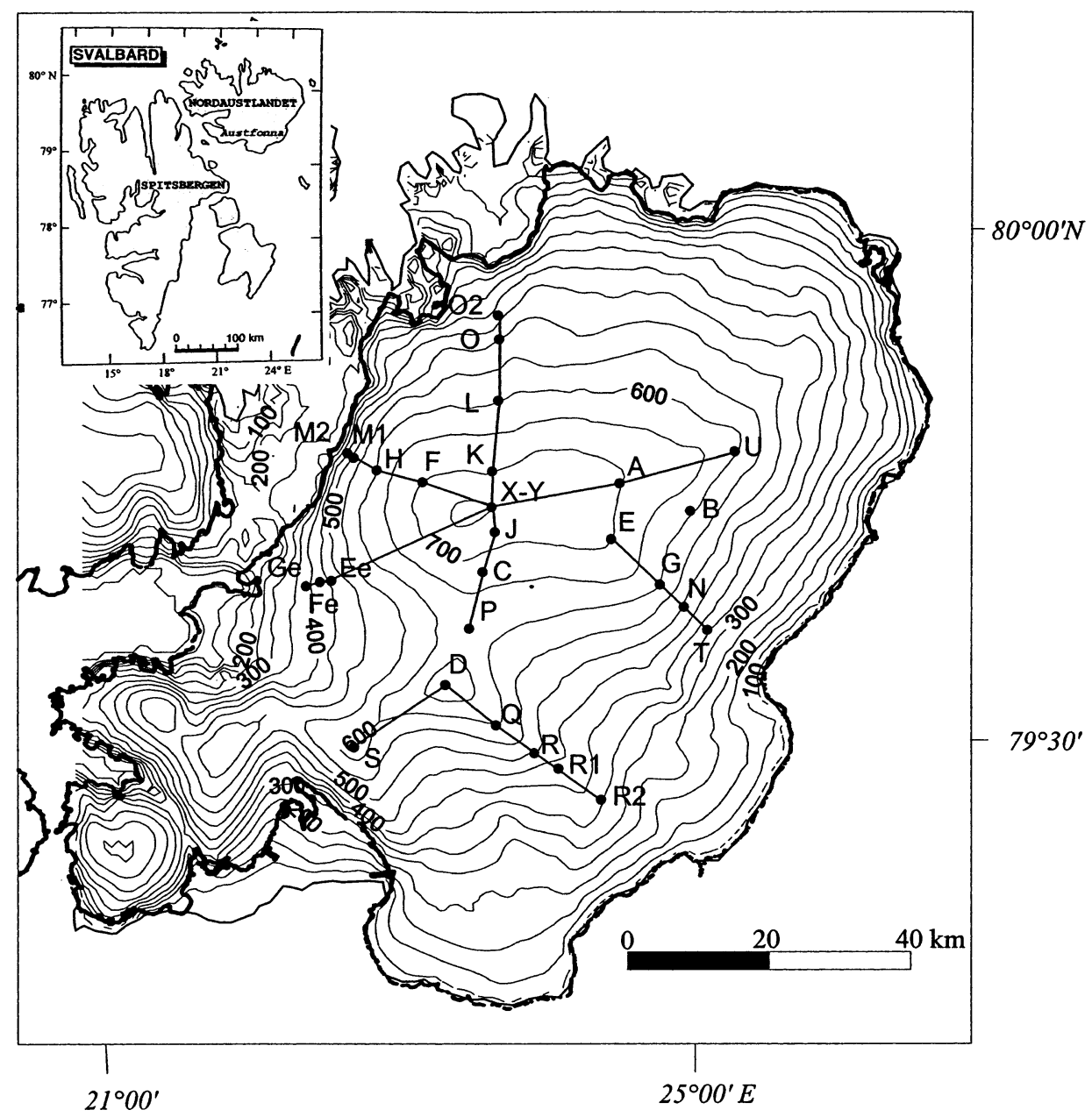

Fig.1. Map of Austfonna, with location of the drilling sites, GPR transects and ice-cap contour and an inset showing the location of Nordaustlandet within Svalbard.

the upper core sections of all ice cores (Table 1). These densities along each transect were used to convert snow-depth measurements from snow-probing and ground-penetrating radar (GPR) measurements to $m$ w.e. depth.

Four snow pits, close to cores X, Y and Z (Fig. 1; Table 1), were studied in April 1999 (personal communication from L. Karlöf, 2000). The most important details in the stratigraphy were the existence of ice layers $(2-5 \mathrm{~cm}$ thick $)$ at $1.1-1.4 \mathrm{~m}$ depth. In a given pit, there are several thin firn or ice layers under the first ice layer. It was evident that the layer at about $1.25 \mathrm{~m}$ represented the late-summer surface of 1998 and that the thin firn and ice layers belonged to earlier periods during the same summer season, associated with surface melting, and followed by percolation some distance into the snowpack before the water refroze and caused the formation of ice layers. This shows that all the snow above this depth was accumulated during winter. Similar multiple layers were also found in the firn cores. Superimposed ice with a density of $900 \mathrm{~kg} \mathrm{~m}^{-3}$ was found just below the winter snow layer for ice cores G, H, L, M1, O, N, R, R1, R2, Tand U (Fig. 1).

Snow temperatures were measured with a thermistor string at core sites A, G, K and E. Despite clearly negative temperatures at $10 \mathrm{~m}$ depth, the temperature gradient indicates that the ice is close to the pressure-melting point at about $20 \mathrm{~m}$. At greater depths, colder ice (about $-8^{\circ} \mathrm{C}$ at $160 \mathrm{~m}$ depth) was found in a deep ice core drilled on the ice cap (Zagorodnov and Arkhipov, 1990). This confirms Schytt's $(1964,1969)$ proposal that the Austfonna ice cap has a subpolar thermal regime characterized by an inner core of temperate ice surrounded by an annulus of cold ice.

\subsection{Core handling and laboratory analyses}

Nuclear weapons tests in the 1950s, 1960s and 1970s, and the Chernobyl accident in 1986, emitted large amounts of manmade radioisotopes (e.g. ${ }^{134} \mathrm{Cs}$ and ${ }^{137} \mathrm{Cs}$ ) into the atmosphere. Some of this material reached glaciers in the Arctic, providing permanent records of deposition. In 1999, the Chernobyl layer in the Austfonna ice cap was never deeper than $9 \mathrm{~m}$, so it was possible to determine the mean annual net mass balance for 12 years over the whole Austfonna accumulation area by retrieving a series of shallow ice cores. In the present study, we identify both natural and artificial radioactive signatures in shallow ice cores drilled in Austfonna in spring 1998 and 1999. We determined the mean snow accumulation from the radioactive layers associated with Chernobyl and the atmospheric nuclear tests layer, the latter having a maximum in 1963 in the Arctic. In addition, GPR methods have been used to derive continuous profiles of the 1998/99 winter snow cover from seven profiles.

After the fieldwork, all the cores were subsampled (cut into sections approximately $15-20 \mathrm{~cm} \mathrm{long}$ ) in cold rooms in order to conduct high-resolution gamma spectrometry. The radiochemical preparation of these samples mainly involved melting, acidification and filtration, and final standardized mounting for gamma radioactivity as described by Delmas and Pourchet (1977). Altogether, the 1999 cores consist of 700 samples for a total length of $175 \mathrm{~m}$, whereas in 1998 we prepared 250 samples for a total length of $90 \mathrm{~m}$. The Japanese deep ice cores were subsampled by the NIPR and the Norwegian Polar Institute (NPI) between the surface and 

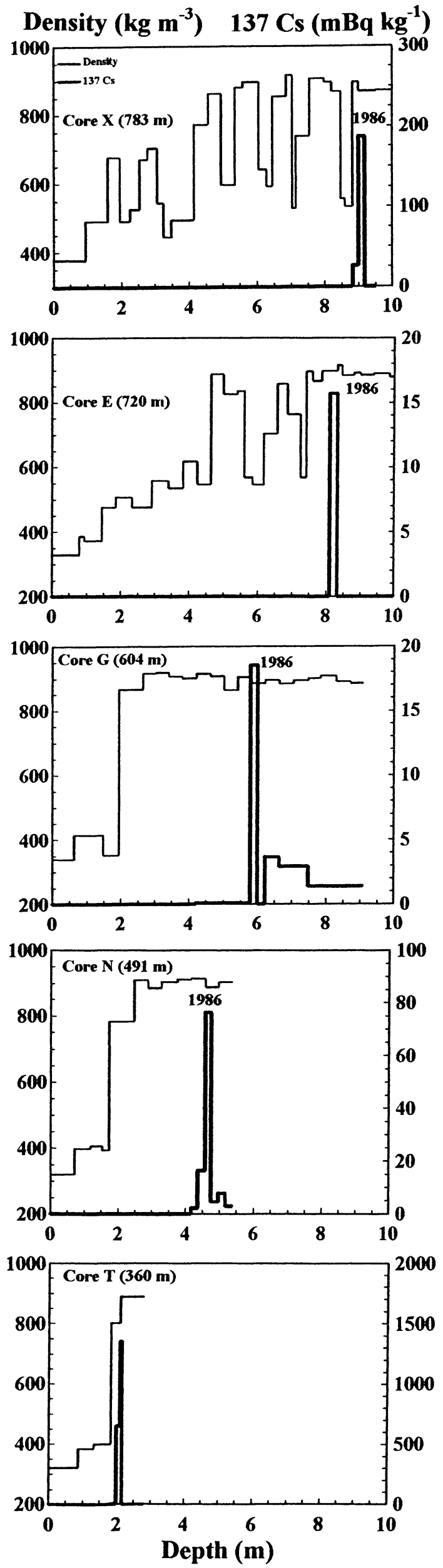

Fig. 2. Snow-ice density and ${ }^{137}$ Cs (from Chernobyl) profiles with depth for the southeast (XEGNT) transect (Fig. 1). Note the changing scale for ${ }^{137}$ Cs.
$40 \mathrm{~m}$ depth for radioactivity and other measurements ( $\mathrm{K}$. Kamiyama and others, unpublished information).

The high-resolution gamma spectrometry analyses were conducted in a specially designed laboratory at the Laboratoire de Glaciologie et Géophysique de l'Environnement, Grenoble (Pinglot and Pourchet, 1994). It was possible to determine both natural and artificial radioactivity in the snowpack. The stratigraphy of the radioactive layers includes ${ }^{137} \mathrm{Cs}$ from the nuclear tests (1954-74) and Chernobyl (1986), as well as ${ }^{210} \mathrm{~Pb}$ of natural atmospheric origin (Pinglot and others, 1994). In order to determine the ${ }^{210} \mathrm{~Pb}$ winter deposition, gamma spectrometry was conducted on the upper samples of the cores representing the winter 1997/98 and 1998/99 snow accumulations.

\subsection{GPR and GPS survey: error analysis and data processing}

During the fieldwork in 1999, we used a RAMAC impulse GPR system operating at $500 \mathrm{MHz}$ and two Ashtech Z-XII global positioning system (GPS) receivers to profile Austfonna. Snow radar and GPS data were collected continuously along $300 \mathrm{~km}$ long traverses following the routes between the core sites (Fig. 1). The dataset comprises approximately 150000 GPR traces and 22000 GPS points. Manual snow-depth measurements were taken at the core sites and at number of intermediate points along the transects. These 50 manually observed snow depths were used to check and calibrate the snow depth obtained by the GPR.

The radar control unit, laptop computer, GPS antenna and receiver were operated from a sledge pulled by a snowmobile. The radar antenna was mounted on a non-metallic sledge pulled $2 \mathrm{~m}$ behind the first sledge with the GPS and GPR units. Each $500 \mathrm{MHz}$ GPR record was collected in the form of 512 samples with a sampling frequency of $4865 \mathrm{MHz}$, giving a time window of $105 \mathrm{~ns}$ for each trace. Eight individual radar returns were stacked to increase the signal-to-noise ratio. This stacked trace was recorded in the laptop computer. To determine locations, differential or kinematic GPS was used. In addition to the on-board GPS receiver (rover), one stationary receiver was located at the camp site. This reference receiver was related to a fixed geodetic point beyond the ice cap. The method is fully described by Eiken and others (1997).

GPR and GPS data were sampled with fixed time intervals of 0.5 and $5 \mathrm{~s}$, respectively. The spatial measurement interval therefore depends on snowmobile speed $\left(\sim 4 \mathrm{~m} \mathrm{~s}^{-1}\right)$, and averaged around 2 and $20 \mathrm{~m}$ for GPR and GPS, respectively.

\subsubsection{GPR processing}

The radar receives signals from different reflectors in the snowpack. In order to obtain quantitative snow-accumulation measurements from GPR data, it is necessary to convert time-dependent radar return signals to depths. The winter 1998/99 snow-ice or snow-firn interface must be identified and separated from the other reflectors. A time-varying gain function was used to amplify the signal at depth. Usually two dominant signals can be observed (Fig. 3): the reflection returned from the surface of the snow cover, which serves as the time reference; and the echo from the snow-firn or snow-ice interface. In the ablation and superimposed-ice area, the snow-ice reflector can easily be identified using the layer reflection intensity since the winter snow cover lies on top of uniform cold ice. In the accumulation area, the snow- 


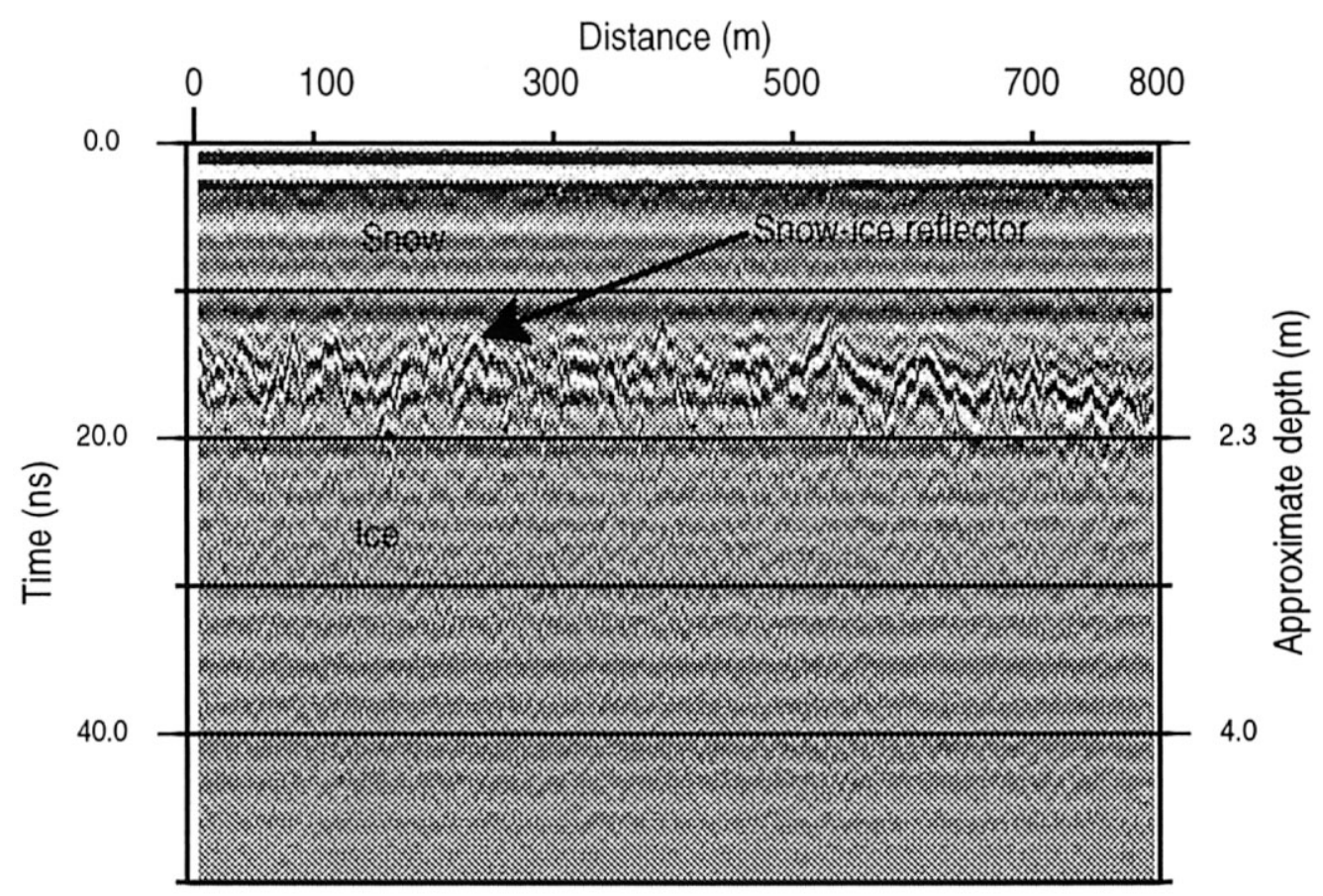

Fig. 3. GPR signals: typical section of a $500 \mathrm{MHz}$ record from the south transect DQRR1R2 around core $R$ ( Fig. 1), which shows a clear reflection from the ice-snow interface. The distance between the traces is approximately $2 \mathrm{~m}$, and a TWT of 10 ns gives a depth of about $1.15 \mathrm{~m}$ in snow. Repeated events (e.g. vertical ellipses) are system ringing.

firn interface is less distinct, due to a less homogeneous and less well-developed summer surface. The snow cover lies on top of heterogeneous firn (firn, superimposed-ice and ice layers), as shown in the pit and ice-core stratigraphy (Fig. 2). The winter 1998/99 snow cover was identified using the layer reflection intensity correlated to the core stratigraphy and manual probing.

To construct a snow-distribution map from these GPR data, the onset time of the surface and snow-ice/snow-firn reflections must be determined. An interactive mouse-driven computer program (SIRDAS Data Analysis System from SUSAR Consulting AS) was used to determine the onset times and the two-way-travel times (TWT) between the snow surface and snow-firn/snow-ice interface along most of the GPR profiles $(80 \%)$. Gaps occurred in the output of the automatic digitizing when the signal from the snow-firn interface was too weak to be determined. In those areas, no accumulation data were obtained from the GPR measurements.

The electromagnetic wave speed $\left(v_{\mathrm{s}}\right)$ through snow and firn can be determined by

$$
v_{\mathrm{s}}=c_{0} / \sqrt{\varepsilon},
$$

where $c_{0}\left(2.988 \times 10^{8} \mathrm{~m} \mathrm{~s}^{-1}\right)$ is the speed of the electromagnetic wave in a vacuum and $\varepsilon$ is the dielectric constant. The dielectric constant, in turn, is a function of several parameters, of which the most important are density and water content (Ulaby and others, 1986; Kovacs and others, 1995). Dry snow and firn are assumed everywhere in spring, and the thermistor data from the core sites show subfreezing temperatures in the upper $10 \mathrm{~m}$ of the snow/firn pack. Density will thus be the most important factor determining the wave propagation speed. The snow densities measured at the core sites varied from 340 to $390 \mathrm{~kg} \mathrm{~m}^{-3}$, averaging to $375 \mathrm{~kg} \mathrm{~m}^{-3}$. Based on empirical models for estimation of the dielectric constant, this should give a dielectric constant close to 1.7, as also used by Winther and others (1998) investigating snow distribution on Spitsbergen, Svalbard. The snow thickness was calculated from the TWT using an average electromag- netic wave velocity in snow of $230 \mathrm{~m} \mathrm{\mu s}^{-1}$, following from using $\varepsilon=1.7$. A constant wave speed was assumed to simplify the depth calculations. Along the GPR profiles, the snow thicknesses were translated into snow accumulation in $\mathrm{m}$ w.e. using the measured depth-density distributions.

\subsubsection{GPR error analysis and data treatment}

The accuracy of the accumulation thus obtained, in $m$ w.e., depends on the accuracy of the wave propagation speed, snow density and interpretation of the radar recordings.

The error introduced by density variations was assessed. The wave propagation speed was estimated using maximum $\left(390 \mathrm{~kg} \mathrm{~m}^{-3}\right)$ and minimum $\left(340 \mathrm{~kg} \mathrm{~m}^{-3}\right)$ densities. The difference in the wave speed between these two cases gave a $4 \%$ difference in the estimated snow depth. The effect on the calculated accumulation could be up to $10 \%$ in the measured depth range $(0.5-3 \mathrm{~m})$.

The automatic digitizer can pick up the onset times from the snow surface to within half the sampling interval, that is equal to about $0.23 \mathrm{~m}$ of snow (Fig. 3). The quality of the reflection from the snow-ice/snow-firn interface, however, is influenced by several factors:

(1) the thickness of the snow cover and the spreading loss,

(2) the roughness of the interface,

(3) interference from nearby reflections rather than a direct representation of the individual discontinuities in impedance themselves (especially in the accumulation area), and

(4) the dielectric constant contrast between the snow and ice or firn below the snow mainly through changes in density (Refzlaff and others, 1993; Rosenberger and others, 1997).

All these factors affect the accuracy of the automatic depth determination.

Moreover, if the wavelengths used are greater than the thickness of the individual ice layer/snow layers, each internal horizon corresponds to interference from several layers 


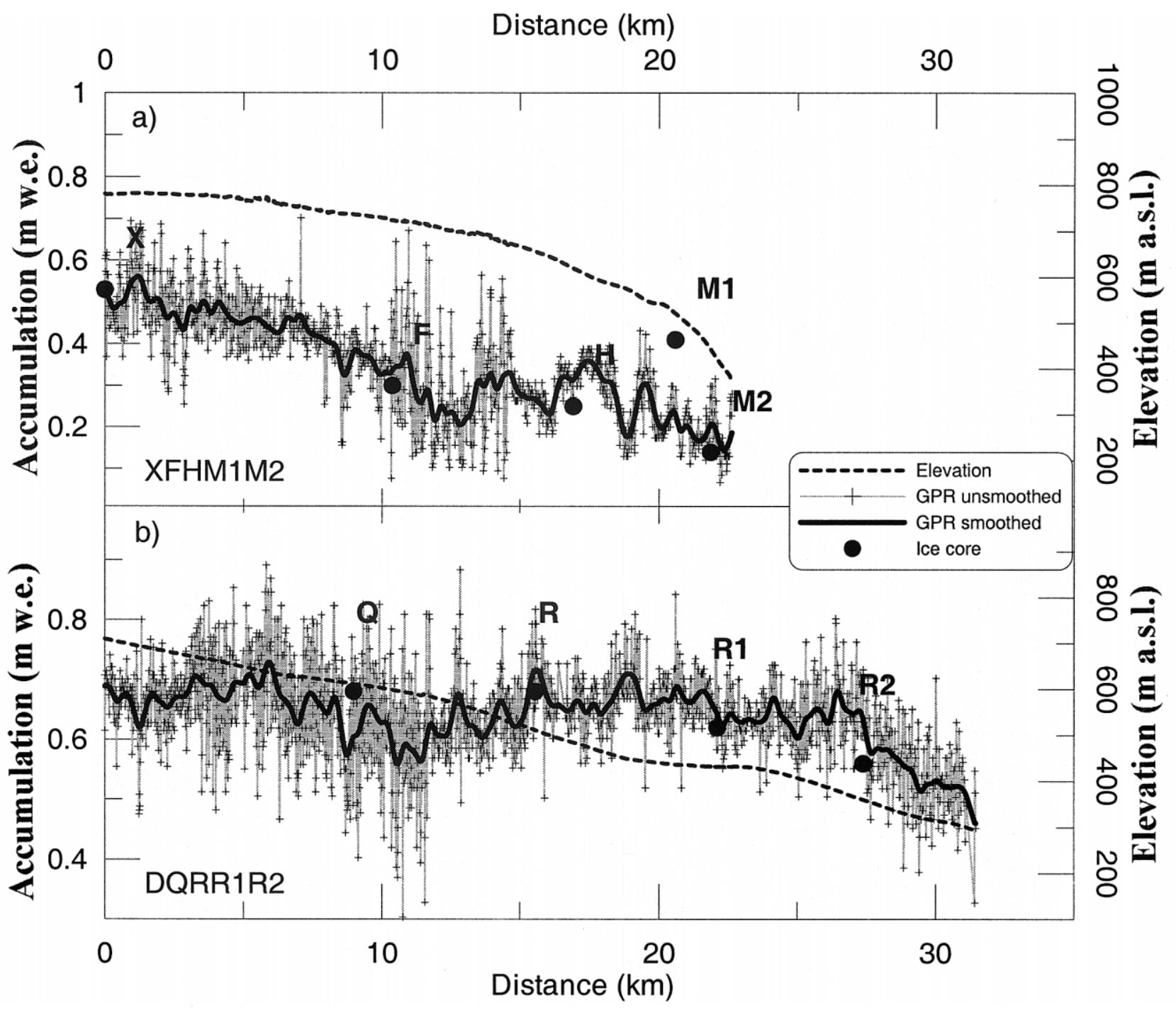

Fig. 4. Snow depth ( $m$ w.e.) and surface elevation (dotted line) for northwest (XFHM1M2) and south (DQRR1R2) transects (located in Fig. 1), measured by radar and GPS. Both unsmoothed and smoothed (thick black line) radar data are shown. Snow depths ( $m$ w.e.) for the core sites along the transects are also shown (black circles).

(Harrison, 1973). Interference could lead to random vertical displacement of some horizons and the visual impression of a high-resolution record. On Austfonna, the pit and core studies show several thin, closely spaced ice-firn layers just below the summer surface. We could thus expect interference in our GPR data which will affect the determination of the onset time for the snow-firn interface and lead to noise in the derived TWT.

The estimated snow accumulation shows large spatial variations over short distances (50-100 m) (Fig. 4a and b). We estimated the variability along transects for spatial averages of groups of data. The variability is given as a coefficient of variation expressed by the ratio of the standard deviation of a given number of accumulation values (25 points $/ 500 \mathrm{~m}$ ) to the mean value. The variability for the different groups of data along transects ranges from roughly $25 \%$ for the groups of data derived from the accumulation area to about $12 \%$ for data from the ablation area. The higher noise signal found in the accumulation area is probably a result of the random vertical displacement of the GPR horizon due to interference of the radar signal and to less homogeneous GPR horizons. By spatially averaging our GPR data we obtained data with low variability, reflecting primarily real spatial differences in the snow-accumulation pattern. All accumulation data were therefore spatially averaged using a 25-point moving average. Analysis of several digitized records indicates an average digitizing error of $5 \mathrm{~cm}$ for the snow-ice reflection and $15 \mathrm{~cm}$ for the snow-firn reflection.

\subsubsection{Differential GPS for positioning}

Ashtech's Precise NAVigation (PNAV) software was used for processing the GPS data. The PNAV software produces the so-called "on-the-fly" (OTF) ambiguity resolution in the measured GPS code and phase data. For OTF initialization, the first few measurements are used to resolve the phase ambiguities, which means determining the integer number of wavelengths between the satellite and the receivers. After this, a Kalman filter is used to calculate both static and kinematic positions. The position of the rover antennae relative to the fixed GPS receivers is then determined along each transect. Static fixed solutions were determined for the beginning and the end of the survey and beside core sites and all points where the snowmobile stopped. The GPS-measured heights are related to sea level by subtracting a constant geoid height of $26.62 \mathrm{~m}$ from the World Geodetic System 1984 (WGS84) derived ellipsoidal heights.

\subsubsection{Geo-coding}

The horizontal and vertical position of the GPR traverses could be determined from the kinematic GPS survey. However, a major obstacle to obtaining an accurate horizontal 
$210 \mathrm{~Pb}\left(\mathrm{~Bq} \mathrm{~m}^{-2}\right)$

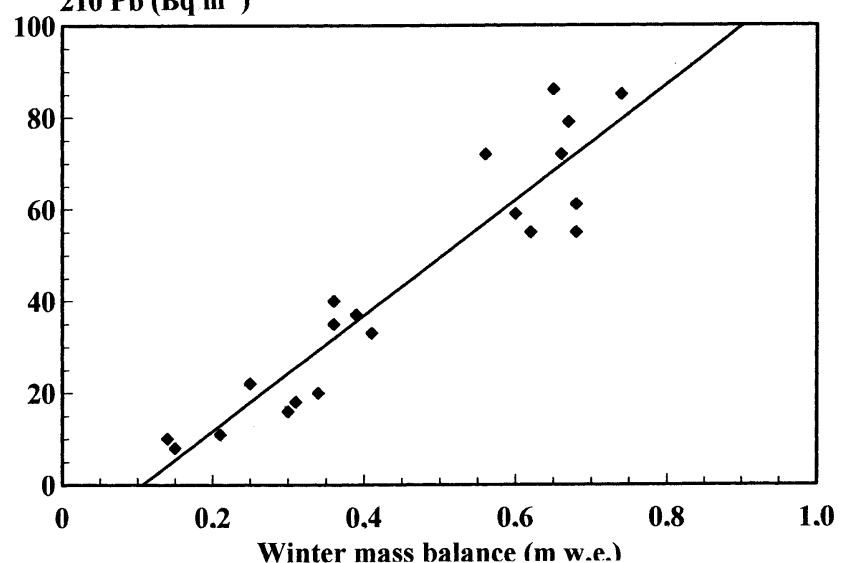

Fig. $5 .{ }^{210}$ Pb fallout vs 1998/99 winter mass balance.

and vertical position of each GPR data point is the relatively poor density of the GPS measurements. GPS data were obtained at $5 \mathrm{~s}$ intervals, and GPR at $0.5 \mathrm{~s}$ intervals. The starting and ending coordinates of the individual GPR transect were measured. The horizontal position of the GPR traces is determined by interpolation, assuming constant velocity and thus equidistant sampling space between the starting and ending coordinates for each GPR file. The elevation is determined by linear interpolation between the closest pair of GPS coordinates for each shot. As a result, locations $(x, y, z)$ were determined to within $0.5 \mathrm{~m}$ both vertically and horizontally for most of the data points.

GPS data were also used to fix the position of core sites and current geometry of the surface, resulting in accuracies of about $1 \mathrm{~m}$ vertically and $5 \mathrm{~m}$ horizontally (Table 1 ).

\section{RESULTS}

\subsection{Radioactivity}

\subsection{1. ${ }^{210} \mathrm{~Pb}$ winter deposition}

The measured ${ }^{210} \mathrm{~Pb}$ (natural isotope) winter deposition shows large annual and interannual variations (Table 1). The mean ${ }^{210} \mathrm{~Pb}$ fallout varies by a factor of 2 between winter 1997/98 (18.6 $\mathrm{Bq} \mathrm{m}^{-2}$ ) and 1998/99 (43.7 $\left.\mathrm{Bq} \mathrm{m}^{-2}\right)$, with standard deviations of 9.6 and $26.5 \mathrm{~Bq} \mathrm{~m}^{-2}$, respectively. From Figure 5 it is evident that there is a clear positive correlation $\left(r^{2}=0.88\right)$ between 1998/99 winter snow-accumulation rate and ${ }^{210} \mathrm{~Pb}$ fallout, with high accumulation rates giving high $\mathrm{Pb}$ depositions. Interannual ${ }^{210} \mathrm{~Pb}$ winter deposition variation can thus be ascribed to differences in accumulation and not to differences in deposition processes.

\subsubsection{Reference and ablation layers}

The Chernobyl layer has been identified in 19 ice cores from the accumulation area (Table 2). The Chernobyl deposition varies from $1 \mathrm{~Bq} \mathrm{~m}^{-2}$ (at core site $\mathrm{J}$ ) up to $47 \mathrm{~Bq} \mathrm{~m}^{-2}$ (at core site $\mathrm{X}$ ), with all activities corrected to 1 January 2000. The mean value for 19 determinations is $10 \mathrm{Bqm}^{-2}$, with a $10 \mathrm{~Bq} \mathrm{~m}^{-2}$ standard deviation. There is no clear relationship with altitude, and a strong spatial variability was observed. For instance, ${ }^{137} \mathrm{Cs}$ depositions of 5 and $47 \mathrm{Bqm}^{-2}$ were measured for ice cores $\mathrm{X}$ and $\mathrm{Z}$ which are situated only a few hundred metres apart.

Figure 2 shows density and ${ }^{137} \mathrm{Cs}$ profiles for ice cores X, E, G, $\mathrm{N}$ and Talong the southeast transect (Fig. 1). The peak in ${ }^{137} \mathrm{Cs}$ corresponding to the Chernobyl layer is clearly seen in
Table 1. Ice-core locations at Austfonna in 1998 and 1999 with mean density of winter snow, accumulation during the 1997/ 98 and 1998/99 winters, and ${ }^{210} \mathrm{~Pb}$ winter deposition over Austfonna

\begin{tabular}{|c|c|c|c|c|c|}
\hline \multirow[t]{2}{*}{$\begin{array}{l}\text { Ice core } \\
\text { (Fig. 1) }\end{array}$} & \multirow[t]{2}{*}{ Location } & \multirow{2}{*}{$\begin{array}{l}\text { Altitude } \\
\text { ma.s.l. }\end{array}$} & \multirow{2}{*}{$\begin{array}{l}\text { Density } \\
\mathrm{kg} \mathrm{m}^{-3}\end{array}$} & \multirow{2}{*}{$\begin{array}{l}\text { Winter } \\
\text { balance } \\
\text { mw.e. }\end{array}$} & \multirow{2}{*}{$\begin{array}{c}{ }^{210} \mathrm{~Pb} \\
\mathrm{~Bq} \mathrm{~m}^{-2}\end{array}$} \\
\hline & & & & & \\
\hline \multicolumn{6}{|l|}{1998} \\
\hline A & $79^{\circ} 50^{\prime} 00^{\prime \prime} \mathrm{N}, 24^{\circ} 56^{\prime} 09^{\prime \prime} \mathrm{E}$ & 729 & 320 & 0.237 & 17 \\
\hline B & $79^{\circ} 47^{\prime} 00^{\prime \prime} \mathrm{N}, 25^{\circ} 24^{\prime} 00^{\prime \prime} \mathrm{E}$ & 586 & 350 & 0.244 & 38 \\
\hline $\mathrm{C}$ & $79^{\circ} 45^{\prime} 00^{\prime \prime} \mathrm{N}, 23^{\circ} 52^{\prime} 00^{\prime \prime} \mathrm{E}$ & 707 & 340 & 0.363 & 20 \\
\hline $\mathrm{D}$ & $79^{\circ} 36^{\prime} 54^{\prime \prime} \mathrm{N}, 23^{\circ} 29^{\prime} 26^{\prime \prime} \mathrm{E}$ & 708 & 330 & 0.306 & 20 \\
\hline $\mathrm{Ee}$ & $79^{\circ} 45^{\prime} 58^{\prime \prime} \mathrm{N}, 22^{\circ} 47^{\prime} 58^{\prime \prime} \mathrm{E}$ & 495 & 310 & 0.217 & 8 \\
\hline $\mathrm{Fe}$ & $79^{\circ} 46^{\prime} 00^{\prime \prime} \mathrm{N}, 22^{\circ} 43^{\prime} 00^{\prime \prime} \mathrm{E}$ & 450 & 350 & 0.191 & 12 \\
\hline $\mathrm{Ge}$ & $79^{\circ} 45^{\prime} 49^{\prime \prime} \mathrm{N}, 22^{\circ} 37^{\prime} 00^{\prime \prime} \mathrm{E}$ & 410 & 350 & 0.162 & 15 \\
\hline $\mathrm{J}$ & $79^{\circ} 47^{\prime} 52^{\prime \prime} \mathrm{N}, 23^{\circ} 59^{\prime} 51^{\prime \prime} \mathrm{E}$ & 758 & 330 & 0.264 & \\
\hline \multicolumn{6}{|l|}{1999} \\
\hline $\mathrm{E}$ & $79^{\circ} 45^{\prime} 54^{\prime \prime} \mathrm{N}, 24^{\circ} 48^{\prime} 35^{\prime \prime} \mathrm{E}$ & 720 & 362 & 0.60 & 59 \\
\hline $\mathrm{F}$ & $79^{\circ} 52^{\prime} 29^{\prime \prime} \mathrm{N}, 23^{\circ} 32^{\prime} 30^{\prime \prime} \mathrm{E}$ & 727 & 354.5 & 0.30 & 16 \\
\hline $\mathrm{G}$ & $79^{\circ} 41^{\prime} 52^{\prime \prime} \mathrm{N}, 25^{\circ} 05^{\prime} 46^{\prime \prime} \mathrm{E}$ & 604 & 380 & 0.74 & 85 \\
\hline $\mathrm{H}$ & $79^{\circ} 53^{\prime} 51^{\prime \prime} \mathrm{N}, 23^{\circ} 13^{\prime} 49^{\prime \prime} \mathrm{E}$ & 619 & 390 & $0.21-0.25$ & 11 \\
\hline $\mathrm{K}$ & $79^{\circ} 52^{\prime} 28^{\prime \prime} \mathrm{N}, 24^{\circ} 02^{\prime} 46^{\prime \prime} \mathrm{E}$ & 728 & 374 & 0.34 & 20 \\
\hline $\mathrm{L}$ & $79^{\circ} 57^{\prime} 45^{\prime \prime} \mathrm{N}, 24^{\circ} 10^{\prime} 11^{\prime \prime} \mathrm{E}$ & 620 & 382 & 0.31 & 18 \\
\hline M1 & $79^{\circ} 55^{\prime} 03^{\prime \prime} \mathrm{N}, 23^{\circ} 04^{\prime} 39^{\prime \prime} \mathrm{E}$ & 521 & 377 & 0.41 & 33 \\
\hline M2 & $79^{\circ} 55^{\prime} 28^{\prime \prime} \mathrm{N}, 23^{\circ} 02^{\prime} 11^{\prime \prime} \mathrm{E}$ & 457 & 337 & 0.14 & 10 \\
\hline $\mathrm{N}$ & $79^{\circ} 39^{\prime} 52^{\prime \prime} \mathrm{N}, 25^{\circ} 14^{\prime} 09^{\prime \prime} \mathrm{E}$ & 491 & 379 & 0.66 & 72 \\
\hline $\mathrm{O}$ & $80^{\circ} 02^{\prime} 23^{\prime \prime} \mathrm{N}, 24^{\circ} 14^{\prime} 49^{\prime \prime} \mathrm{E}$ & 506 & 370 & $0.15-0.28$ & 8 \\
\hline $\mathrm{O} 2$ & $80^{\circ} 04^{\prime} 13^{\prime \prime} \mathrm{N}, 24^{\circ} 16^{\prime} 01^{\prime \prime} \mathrm{E}$ & 435 & 325 & 0.25 & 22 \\
\hline $\mathrm{P}$ & $79^{\circ} 40^{\prime} 52^{\prime \prime} \mathrm{N}, 23^{\circ} 42^{\prime} 47^{\prime \prime} \mathrm{E}$ & 653 & 366 & 0.35 & 40 \\
\hline Q & $79^{\circ} 33^{\prime} 15^{\prime \prime} \mathrm{N}, 23^{\circ} 47^{\prime} 49^{\prime \prime} \mathrm{E}$ & 613 & 383 & 0.68 & 55 \\
\hline $\mathrm{R}$ & $79^{\circ} 30^{\prime} 42^{\prime \prime} \mathrm{N}, 24^{\circ} 01^{\prime} 58^{\prime \prime} \mathrm{E}$ & 511 & 374.5 & 0.68 & 61 \\
\hline $\mathrm{R} 1$ & $79^{\circ} 29^{\prime} 15^{\prime \prime} \mathrm{N}, 24^{\circ} 10^{\prime} 51^{\prime \prime} \mathrm{E}$ & 433 & 369 & 0.62 & 55 \\
\hline $\mathrm{R} 2$ & $79^{\circ} 26^{\prime} 22^{\prime \prime} \mathrm{N}, 24^{\circ} 26^{\prime} 23^{\prime \prime} \mathrm{E}$ & 365 & 343 & 0.56 & 72 \\
\hline S & $79^{\circ} 33^{\prime} 08^{\prime \prime} \mathrm{N}, 22^{\circ} 47^{\prime} 57^{\prime \prime} \mathrm{E}$ & 651 & 366.5 & 0.39 & 37 \\
\hline $\mathrm{T}$ & $79^{\circ} 37^{\prime} 49^{\prime \prime} \mathrm{N}, 25^{\circ} 22^{\prime} 11^{\prime \prime} \mathrm{E}$ & 360 & 369 & 0.67 & 79 \\
\hline $\mathrm{U}$ & $79^{\circ} 50^{\prime} 52^{\prime \prime} \mathrm{N}, 25^{\circ} 47^{\prime} 19^{\prime \prime} \mathrm{E}$ & 619 & 382 & 0.65 & 86 \\
\hline $\mathrm{X}, \mathrm{Y}, \mathrm{Z}$ & $79^{\circ} 49^{\prime} 48^{\prime \prime} \mathrm{N}, 24^{\circ} 00^{\prime} 05^{\prime \prime} \mathrm{E}$ & 783 & 378 & $0.36-0.47$ & 35 \\
\hline
\end{tabular}

Table 2. Detection of the Chernobyl layer in the 1998 and 1999 Austfonna ice cores: real and w.e. depths, ${ }^{137}$ Cs deposition (on 1 January 2000), winter mass balance and MANMB ( min. and max. values, for the time period from 1986 to the date of drilling)

\begin{tabular}{|c|c|c|c|c|c|}
\hline \multirow[t]{2}{*}{ Ice core (Fig. 1) } & \multirow[t]{2}{*}{ Sample No. } & \multicolumn{2}{|c|}{ Chernobyl layer depth } & \multirow{2}{*}{$\begin{array}{c}{ }^{137} \mathrm{Cs} \\
\mathrm{Bqm} \mathrm{m}^{-2}\end{array}$} & \multirow{2}{*}{$\begin{array}{l}M A \mathcal{N} M B \\
\text { m w.e. } \mathrm{a}^{-1}\end{array}$} \\
\hline & & $\mathrm{m}$ & mw.e. & & \\
\hline \multicolumn{6}{|l|}{1998} \\
\hline A & 20 & $8.19-8.55$ & $4.66-4.97$ & 2 & $0.41-0.43$ \\
\hline $\mathrm{B}$ & 20 & $6.05-6.27$ & $3.86-4.04$ & 14 & $0.33-0.35$ \\
\hline $\mathrm{C}$ & 28 & $8.29-8.67$ & $6.12-6.45$ & 14 & $0.53-0.55$ \\
\hline $\mathrm{D}$ & 21 & $7.47-7.78$ & $3.93-4.20$ & 11 & $0.33-0.35$ \\
\hline $\mathrm{J}$ & 21 to 25 & $8.82-10.47$ & $5.24-6.66$ & 1 & $0.46-0.58$ \\
\hline \multicolumn{6}{|l|}{1999} \\
\hline $\mathrm{E}$ & $22-2$ & $8.10-8.32$ & $4.86-5.05$ & 4 & $0.355-0.37$ \\
\hline $\mathrm{F}$ & 16 & $6.41-6.65$ & $4.67-4.89$ & 9 & $0.36-0.38$ \\
\hline G & $14-1$ & $5.78-5.99$ & $4.17-4.36$ & 11 & $0.29-0.30$ \\
\hline $\mathrm{H}$ & 10 & $3.31-3.53$ & $2.68-2.87$ & 24 & $0.21-0.22$ \\
\hline $\mathrm{K}$ & 19 & $7.27-7.59$ & $4.64-4.92$ & 2 & $0.36-0.38$ \\
\hline $\mathrm{L}$ & 13 & $4.44-4.78$ & $3.59-3.89$ & 6 & $0.30-0.32$ \\
\hline $\mathrm{N}$ & $10-2$ & $4.36-4.58$ & $2.93-3.12$ & 13 & $0.19-0.205$ \\
\hline $\mathrm{P}$ & $19-2$ & $8.32-8.49$ & $6.16-6.31$ & 11 & $0.48-0.50$ \\
\hline Q & $16-2$ & $6.57-6.79$ & $4.04-4.24$ & 7 & $0.28-0.30$ \\
\hline$\widetilde{\mathrm{R}}$ & 10 & $4.64-5.01$ & $3.20-3.54$ & 3 & $0.21-0.24$ \\
\hline $\mathrm{S}$ & 18-1 & $7.19-7.37$ & $4.45-4.60$ & 4 & $0.34-0.35$ \\
\hline $\mathrm{U}$ & $12-1$ to $12-2$ & $4.58-5.07$ & $3.13-3.55$ & 2 & $0.21-0.24$ \\
\hline $\mathrm{X}$ & 25 & $8.81-8.98$ & $5.76-5.91$ & 47 & $0.45-0.46$ \\
\hline $\mathrm{Z}$ & 9 & $8.09-8.95$ & $4.65-5.30$ & 5 & $0.39-0.445$ \\
\hline
\end{tabular}


$210 \mathrm{~Pb}\left(\mathrm{~Bq} \mathrm{~m}^{-2}\right)$

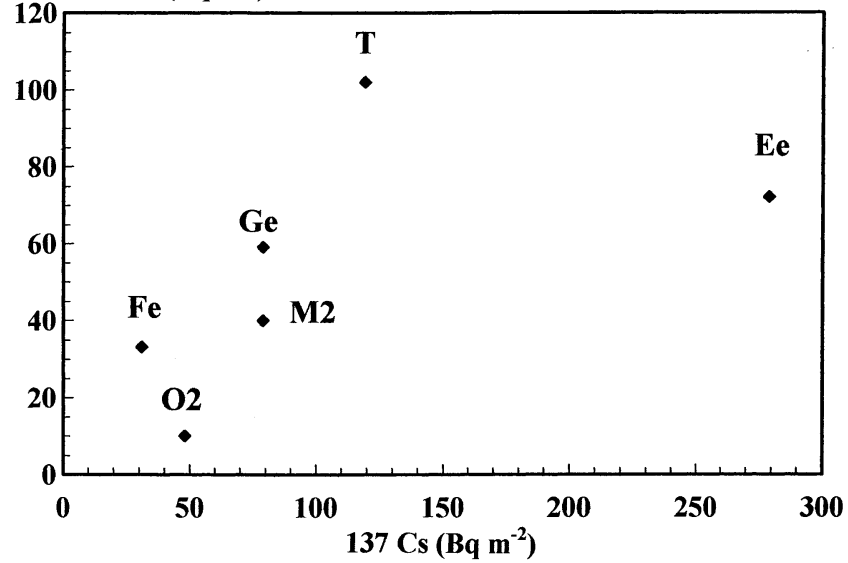

Fig. 6. ${ }^{210} \mathrm{~Pb}$ vs ${ }^{137} \mathrm{Cs}$ deposition for cores $\mathrm{Ee}, \mathrm{Fe}, \mathrm{Ge}, \mathrm{M} 2, \mathrm{O} 2$ and T (located in Fig. 1).

one sample (15-30 cm long) along each core. The depth ranges in Table 2 correspond to the length of the sample. As the altitude decreases from ice core X (783 m) to ice core N (491 m), the Chernobyl layer depth decreases from $8.9 \mathrm{~m}$ to $4.47 \mathrm{~m}$.

The concentration of ${ }^{137} \mathrm{Cs}$ in core $\mathrm{T}$ is an order of magnitude larger than in the other cores along the transect. Similar high ${ }^{137} \mathrm{Cs}$ concentrations are present in cores Fe, Ge, Ee, M2 and O2 (Table 3). In all these cores, the high ${ }^{137}$ Cs concentration was found just below the winter 1997/98 and 1998/99 snow covers. In ice core T the ${ }^{137}$ Cs concentration is as high as $1353 \mathrm{mBq} \mathrm{kg}^{-1}$ and the deposition is $119 \mathrm{~Bq}$ $\mathrm{m}^{-2}$ (Fig. 2). This concentration is much higher than that found in the 19 cores where the Chernobyl layer is present (cf. ${ }^{137} \mathrm{Cs}$ values in Tables 2 and 3). High concentrations of ${ }^{137} \mathrm{Cs}$ and ${ }^{210} \mathrm{~Pb}$ have also been found in ice cores drilled on Kongsvegen (Lefauconnier and others, 1994) and Finsterwalderbreen, Spitsbergen (Pinglot and others, 1997). These authors attributed this to the drilling of these cores in the ablation area, where all artificial radioactive deposits are concentrated, giving rise to high measured values. The dust layer formed at the surface in the ablation area acts as a filter that traps radioactive materials that have been removed from the basin. High concentrations thus indicate that the cores are drilled in the ablation area. In Figure 6, the respective concentrations of ${ }^{137} \mathrm{Cs}$ and ${ }^{210} \mathrm{~Pb}$ isotopes are plotted for cores Fe, Ge, Ee, M2, O2 and T. There is a strong positive correlation between the two isotopes. This suggests that the concentration process of radioactive materials is the same for both artificial and natural radioactivity. This is in accordance with previous work on other Svalbard glaciers (Pinglot and others, 1997).

In cores M1, O, R1 and R2, only negligible amounts of ${ }^{210} \mathrm{~Pb}$ and ${ }^{137} \mathrm{Cs}$ fallout were found. Based on their positions, we propose that the cores are from the accumulation area (Table 3), but, since melting and percolation are quite intense, the deposited particles may have been washed out of the snowpack or transported to greater depths. The mean annual accumulation at these locations could only be deduced by extrapolation from the mean annual net massbalance gradients.

In core $\mathrm{J}$ we found two peaks in the ${ }^{137} \mathrm{Cs}$ radioactivity profile: one at an original deposition depth of $8.82 \mathrm{~m}$, extending down to $10.47 \mathrm{~m}$ (Table 2), and the second at a depth of 22.53-22.88 m. These peaks correspond to deposition from the Chernobyl accident in 1986 and the nuclear tests (195474) which led to a radioactivity peak in 1963.
Table $3 .{ }^{137}$ Cs and ${ }^{210} \mathrm{~Pb}$ deposition of the dust layers

\begin{tabular}{|c|c|c|c|c|}
\hline \multirow[t]{2}{*}{ Ice core (Fig. 1) } & Altitude & ${ }^{137}$ Cs & ${ }^{210} \mathrm{~Pb}$ & $M A \mathcal{N} M B$ \\
\hline & m a.s.l. & $\mathrm{Bqm}^{-2}$ & $\mathrm{Bqm}^{-2}$ & mw.e. \\
\hline $\mathrm{Ee}$ & 495 & 279 & 72 & 0 \\
\hline $\mathrm{Fe}$ & 450 & 31 & 33 & 0 \\
\hline $\mathrm{Ge}$ & 410 & 79 & 59 & 0 \\
\hline M1 & 521 & 0 & n.d. & $0.09^{*}$ \\
\hline M2 & 457 & 79 & 40 & 0 \\
\hline $\mathrm{O}$ & 506 & 0 & n.d. & $0.11^{*}$ \\
\hline $\mathrm{O} 2$ & 435 & 48 & 10 & 0 \\
\hline $\mathrm{R} 1$ & 433 & 0 & n.d. & $0.18^{*}$ \\
\hline $\mathrm{R} 2$ & 365 & 0 & n.d. & $0.14^{*}$ \\
\hline $\mathrm{T}$ & 360 & 119 & 102 & 0 \\
\hline
\end{tabular}

* Mass balance based on extrapolation (n.d. means not detected).

\subsection{Winter accumulation}

Results from the radar soundings together with surface elevations and snow accumulation (winter mass balance) at icecore locations along the northwest transect are presented in Figure 4a (XFHM1M2 (22 km) in Fig. 1). GPR sounding data yield additional information on winter snow-accumulation distribution between the core sites. The GPR data were tuned to the depth of the previous summer surface. The accumulation from pit studies shows substantial variability over short distances. This presumably reflects real spatial variability owing to wind scouring and redeposition, and indicates that individual measurements are not a reliable estimator of the average accumulation rates. Figure 4 shows the limited representativeness of the manual snow-accumulation measurements. It shows that there are marked spatial variations in accumulation rates over both short and long distances along the transects. The smoothed snow accumulation (Fig. 4a) ranges from 0.14 to $0.56 \mathrm{~m}$ w.e., with a $0.35 \mathrm{~m}$ w.e. mean value. There is a clear correlation between elevation and snow depth, with values ranging from $<0.20 \mathrm{~m}$ w.e. at about $375 \mathrm{~m}$ a.s.l. to $>0.60 \mathrm{~m}$ w.e. at $780 \mathrm{~m}$ a.s.l.

Data are also shown for the south transect (Fig. 4b, DQRR1R2 in Fig. 1). As with the other profile, there is a relationship between elevation and snow depth ranging from $0.46 \mathrm{~m}$ w.e. at $300 \mathrm{~m}$ a.s.l. to $0.69 \mathrm{~m}$ w.e. at $600 \mathrm{~m}$ a.s.l.. Between 0 and $20 \mathrm{~km}$, there is a decrease in the snow accumulation with increasing elevation. The smoothed snow accumulation ranges from 0.50 to $0.73 \mathrm{~m}$ w.e., with a $0.64 \mathrm{~m}$ w.e. mean value. The amount of accumulation along the south transect is about $0.30 \mathrm{~m}$ higher than for the northwest transect. The accumulation as a function of elevation varies between the two transects, $\sim 0.09 \mathrm{~m}$ per $100 \mathrm{~m}$ and $\sim 0.03 \mathrm{~m}$ per $100 \mathrm{~m}$, respectively. These two profiles are situated northwest and southeast of the main ice divide (Fig. 1). Similar changes in snow-accumulation gradient could also be seen from the eastern to the western part of the main ice divide, with highest accumulation in the east.

These data have therefore been used to construct the map of the winter accumulation for 1998/99 as shown in Figure 7. The accuracy of the map is quite high along the transects, and decreases rapidly with increasing distance from them. It shows the overall snow-accumulation pattern on the ice cap, including the main trends, with decreasing values from east to west and from south to north. The 1998/99 winter accumulation decreases from $0.65 \mathrm{~m}$ w.e. in the southeastern areas down to about half this value in the northwestern areas. 


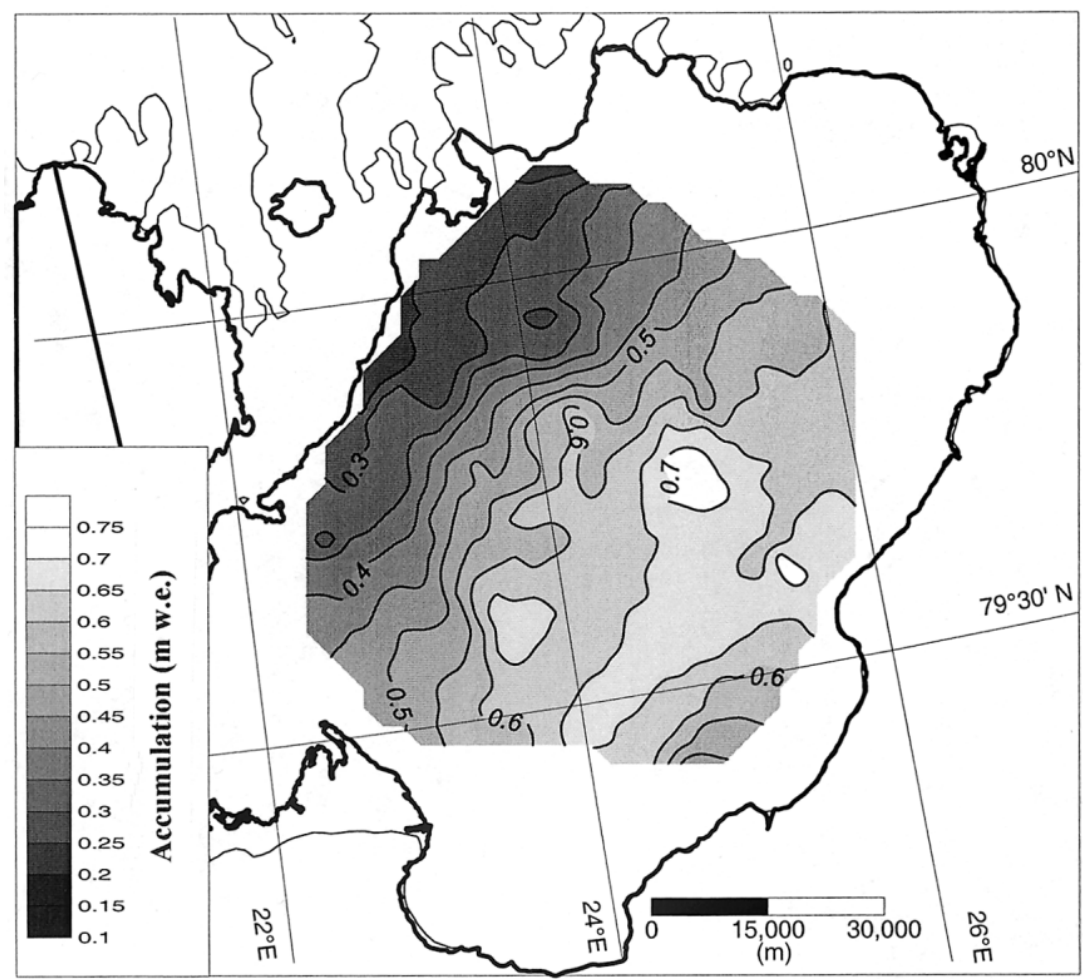

Fig. 7. Distribution map of the 1998/99 winter mass balance ( $m$ w.e.) on Austfonna, based on ice cores and GPR measurements.

Based on the snow distribution in Figure 7, the winter accumulation on Austfonna was calculated to be $2.69 \times 10^{6}$ $\mathrm{m}^{3}$, on the $5474 \mathrm{~km}^{2}$ investigated area of the ice cap, corresponding to an average $0.49 \mathrm{~m}$ w.e. of snow accumulation.

Table 1 shows winter accumulation for winters 1997/98 and 1998/99 found at the core sites, with values (based on 8 and 20 measurements made on a large part of the ice cap) of $0.25 \pm 0.06$ and $0.45 \pm 0.02 \mathrm{~m}$ w.e., respectively. Similar differences were found by Schytt (1964), with a total accumulation for 1957/58 that was 50\% higher than for 1956/57.

\subsection{Mean annual net mass balance}

The mean annual net mass balance (MANMB) for the period from 1986 to the date of the core retrieval has been determined for the 19 cores where the Chernobyl reference layer is preserved. After translation to $\mathrm{m}$ w.e. and divided by the time-span between core retrieval and the datum stratum, and with subtraction of the winter 1997/98 and 1998/99 snow layers, the MANMBs were determined over 12 or 13 years $\left({ }^{137}\right.$ Cs fallout from 1986 to 1998 or 1999). The measured net

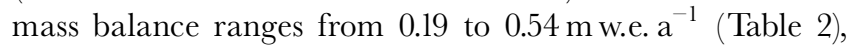
and the variations mainly depend on the altitude (Fig. 8). The MANMB is not constant for a given altitude, however. For instance, it is 0.34 and $0.54 \mathrm{mw}$.e. at ice cores D (708 $\mathrm{m}$ a.s.l.) and $\mathrm{C}$ (707 $\mathrm{m}$ a.s.l.), respectively. The MANMB exhibits maximum values $(0.53-0.55 \mathrm{~m}$ w.e.) close to the top of the ice cap (Fig. 9). A $0.05 \mathrm{~m}$ w.e. MANMB was determined at Isdomen $\left(79^{\circ} 33^{\prime} \mathrm{N}, 25^{\circ} 05^{\prime} \mathrm{E}\right.$; $374 \mathrm{~m}$ a.s.l.) (Dowdeswell and Drewry, 1989). This is in accordance with our results.

The MANMB values are higher than the 1997/98 winter mass balances (Table 3). This is also true for eight ice cores retrieved in 1999 compared to the 1998/99 winter mass balances. This demonstrates that these winter 1998/99 mass balances have lower values than the mean value over the last 12-13 years.

The mean equilibrium-line altitudes (ELAs) are determined for five transects, fitting the observations to a linear altitudinal gradient of the MANMB (Fig. 8a-e). From these gradients the MANMB could be estimated for cores $\mathrm{Ml}, \mathrm{O}$, R1 and R2 (Table 3). The northwest transect (XFHM1M2) indicates an ELA at $472 \mathrm{~m}$ a.s.l. and a mean snow-accumulation gradient of $0.15 \mathrm{mw}$.e. per $100 \mathrm{~m}$. The southeast (XEGNT) and south (DQRR1R2) transects show quite different values. For the southeast transect, the ELA is as low as $339 \mathrm{~m}$ a.s.l. and the gradient is $0.10 \mathrm{~m}$ w.e. per $100 \mathrm{~m}$. This is in agreement with the thicker winter snow layer deposited in this area. These determinations are also in close agreement with earlier investigations. Schytt (1964) indicated 450 and $300 \mathrm{~m}$ a.s.l. ELAs for west Vestfonna and northeast Austfonna, respectively; Dowdeswell and Drewry (1989) determined an ELA at 330-400 m a.s.l. for northeast Austfonna. The south transect shows a gradient of $0.06 \mathrm{~m}$ w.e. per $100 \mathrm{~m}$, along with a surprisingly low ELA at $124 \mathrm{~m}$ a.s.l. that gives a very large accumulation-area ratio (AAR). This determination for Bråsvellbreen may explain the surge character in this part of Austfonna (largest surge in Svalbard in 1937). From the determination of the ELAs, the AAR is 0.45. These ELAs and gradients found at Austfonna can be compared to values for other Svalbard glaciers. The ELA in 1980 at nearby Storöya was about $115 \mathrm{~m}$ a.s.l. (Jonsson, 1982). Kongsvegen and Kronebreen in northwest Spitsbergen have higher ELAs at 500 and $650 \mathrm{~m}$ a.s.l., respectively, and much higher net massbalance gradients of 0.33 and $0.32 \mathrm{~m}$ w.e. per $100 \mathrm{~m}$, respectively. The difference is due to a more maritime climate on the west coast of Spitsbergen than on Nordaustlandet.

A map of the MANMB in the accumulation area was formed based on the 19 ice cores in the accumulation area, the ELA variations and the location of six cores (Ee, Fe, Ge, M2, O2 and T) in the ablation area (Fig. 9). The larger accumulation areas are located to the east and south of the ice divide (Dowdeswell and Cooper, 1986). The map allows us to calculate the mean annual net mass budget of the Austfonna accumulation area (Table 4).

Based on the two peaks in ${ }^{137} \mathrm{Cs}$ radioactivity found in the 1998 Japanese deep core, it was possible to estimate the 
Altitude (m)
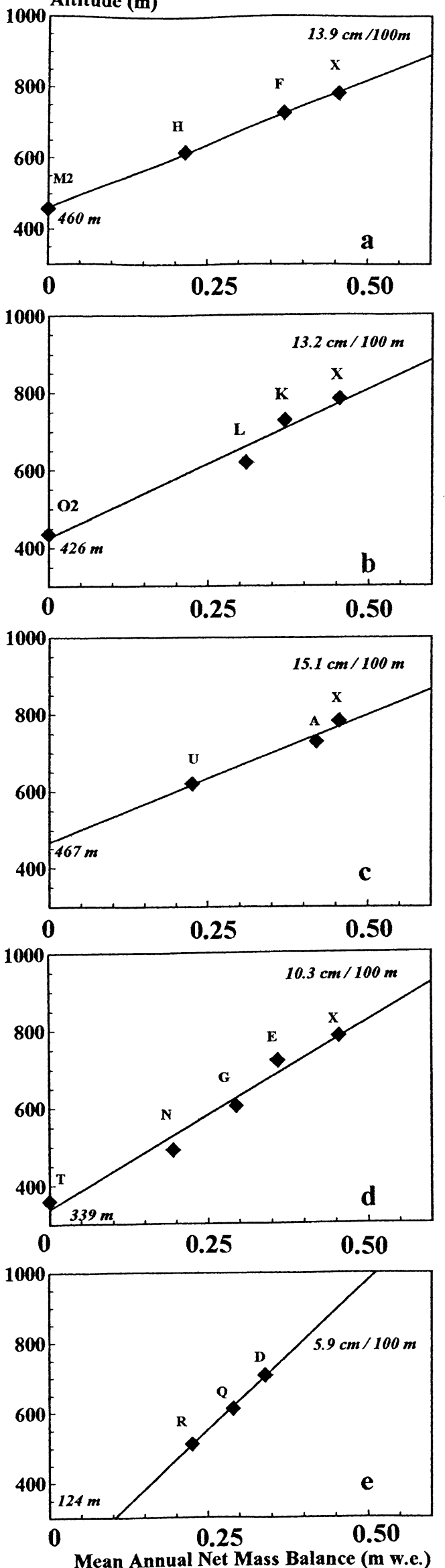

Fig. 8. Relationship between MANMB at the core sites and altitude (Fig. 1), for five different transects: (a) northwest (XFHM1M2); (b) north (XKLOO2); (c) east (XAU); (d) southeast (XEGNT); (e) south (DQRR1R2). The altitudinal gradients (cmw.e. per $100 \mathrm{~m}$ ) and the ELAs $(\mathrm{m})$ are noted in italic for each transect.
Table 4. Distribution of the area and total mass budget for the different mean annual net mass-balance isopleths on Austfonna (Fig. 9)

\begin{tabular}{ccc} 
Mass-balance interval & Area between isopleths & Total mass budget \\
mw.e. $\mathrm{a}^{-1}$ & $\mathrm{~km}^{2}$ & $10^{6} \mathrm{~m}^{3}$ \\
\hline$>0.50$ & 138 & 72 \\
$0.40-0.50$ & 468 & 211 \\
$0.30-0.40$ & 1092 & 382 \\
$0.20-0.30$ & 698 & 174 \\
$0.00-0.20$ & 1426 & 143 \\
$0.00->0.50$ & 3822 & 982
\end{tabular}

MANMB for two separate periods, 1963-86 and 1986-97: 0.50 and $0.52 \mathrm{~m}$ w.e., respectively. This difference is not significant. The temporal variation of the MANMB has previously been studied from ice cores over Svalbard, using the same dating horizons. MANMB at these locations does not indicate any significant change on Svalbard either (Pinglot and others, 1999).

\section{DISCUSSION}

\section{1. ${ }^{137} \mathrm{Cs}$ and ${ }^{210} \mathrm{~Pb}$ depositions}

A number of studies have been carried out on glaciers in Svalbard to determine the ${ }^{137}$ Cs deposition in the Chernobyl layer (Pinglot and others, 1994). In general, the deposition on Austfonna varies widely, from only a few $\mathrm{Bq} \mathrm{m}^{-2}$ up to $47 \mathrm{~Bq} \mathrm{~m}^{-2}$, with a mean of $10 \mathrm{~Bq} \mathrm{~m}^{-2}$ (19 cores in the accumulation area) (Fig. 9). Larger variations are also found for cores drilled only a few hundred metres apart (e.g. Austfonna cores $\mathrm{X}$ and $\mathrm{Z}$, respectively 5 and $47 \mathrm{~Bq} \mathrm{~m}^{-2}$ ). These variations must be due to different amounts of fallout or post-depositional processes.

In Svalbard, the radioactivity due to the Chernobyl accident arrived in early May 1986. On Austfonna, the first snow containing ${ }^{134} \mathrm{Cs}_{\mathrm{s}}$ and ${ }^{137} \mathrm{Cs}$ radioactive elements fell on 4 May, whereas the main deposition occurred during 10-11 May, when a strong low-pressure system with strong precipitation passed Svalbard and Nordaustlandet (Pourchet and others, 1986). A similar fallout pattern in time was found in Ny-Ålesund. The fallout decreased rapidly after this event since the Chernobyl emission was restricted to the troposphere, where residence times are relatively short. The resulting deposition thus occurred over a relatively short period, and is mainly due to several distinct snowfalls that could easily be affected by post-depositional processes. Moreover, a part of this radioactivity could have propagated downward, due to melting and percolation processes, especially during warm summers. From the ${ }^{137} \mathrm{Cs}$ profiles for cores $\mathrm{X}, \mathrm{E}, \mathrm{G}$ and $\mathrm{N}$ it is clear that melting and percolation are not very active at these locations; the Chernobyl layer is well preserved and occurs even at lower elevations. Melting and percolation has been identified in ice cores drilled on other Svalbard glaciers (Pinglot and others, 1994). The large spatial variations indicate that there are effects of redeposition of snow by the wind in the period just after the Chernobyl deposition. We compared the average ${ }^{137}$ Cs deposition from the Austfonna ice cores with that of other cores drilled in Svalbard (Pinglot and others, 1994). The depositions were $10 \pm 10 \mathrm{~Bq} \mathrm{~m}^{-2}$ and $7.6 \mathrm{~Bq} \mathrm{~m}^{-2}$, respectively. This shows that 


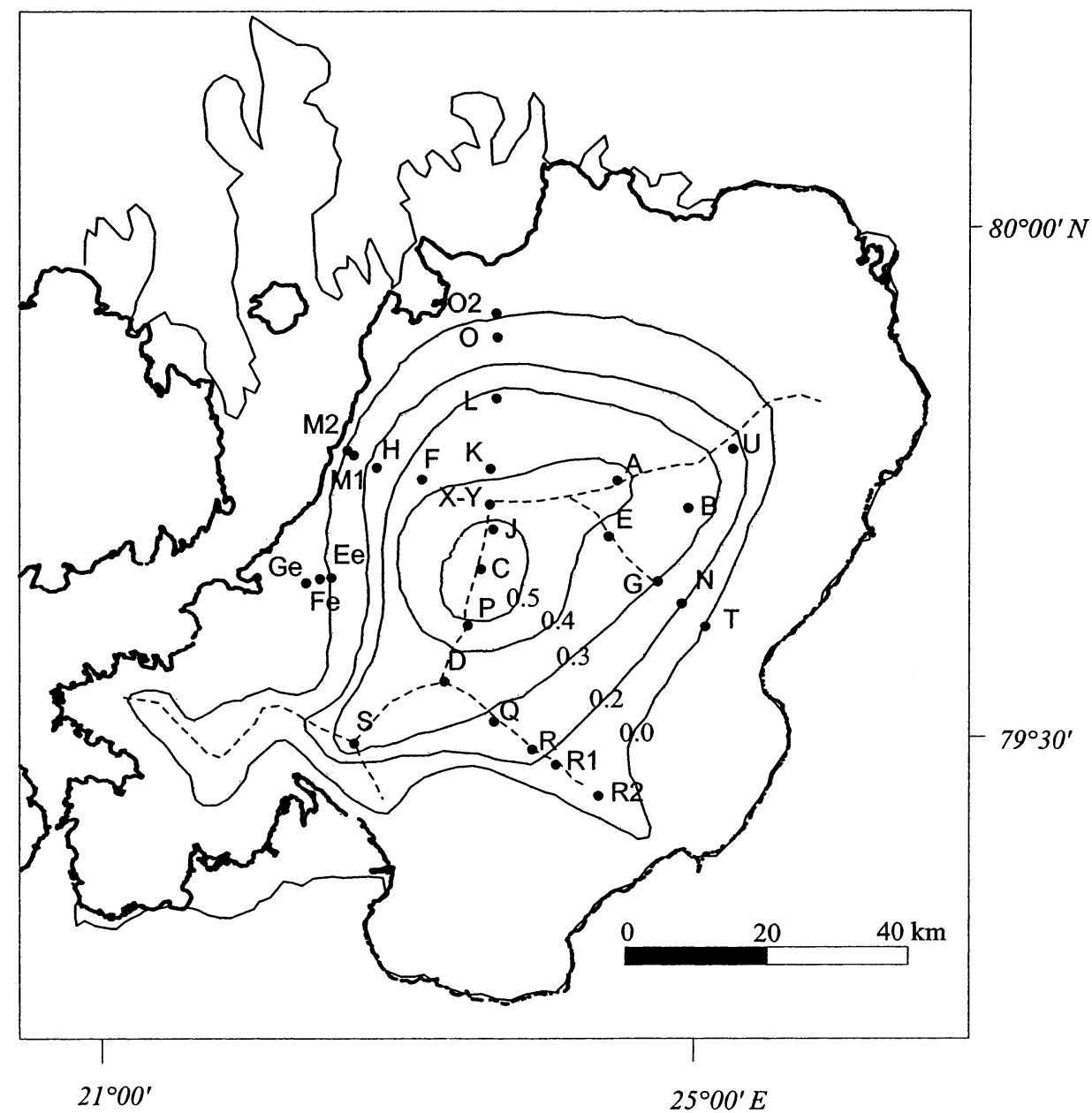

Fig. 9. Distribution map of the MANMB ( $m$ w.e.) on Austfonna. Isopleths correspond to MANMB contours: 0.5, 0.4, 0.3, 0.2 and $0.0 \mathrm{~m}$ we.e. $a^{-1}$. Dashed lines represent the main ice divides.

the average deposition values are similar over the Svalbard archipelago. The deposition processes indicate that wet deposition is very efficient for ${ }^{210} \mathrm{~Pb}$, while wind scouring affects sudden events such as Chernobyl.

The ${ }^{137}$ Cs fallout from thermonuclear tests found in core J is compared with data from previous studies from Svalbard glaciers (Pinglot and others, 1994). A ${ }^{137}$ Cs deposition of $288 \mathrm{~Bq} \mathrm{~m}^{-2}$ (mean value for nine ice cores) is found and, as already mentioned, the ${ }^{137} \mathrm{Cs}$ fallout from atmospheric thermonuclear tests is about 10-20 times that of Chernobyl fallout.

The high correlation between ${ }^{210} \mathrm{~Pb}$ winter deposition and winter accumulation rates indicates a common deposition process. The closely linear relationship results from the fact that the ${ }^{210} \mathrm{~Pb}$ concentration is homogeneous in the air masses over Svalbard.

Variations in ${ }^{210} \mathrm{~Pb}$ winter deposition are due to differences in the amount of winter accumulation rather than differences in the deposition processes. This means that the wet deposition of ${ }^{210} \mathrm{~Pb}$ by snowfall is very efficient (Preiss and others, 1996).

\subsection{Winter accumulation 1998/99}

GPR methods have been used to map the winter 1998/99 snow distribution over Austfonna. Radar soundings can yield valuable data; they give high-resolution data between the core sites, but the interpretation of the GPR images may, at least in some cases, be a matter of subjective judgment. However, if an accumulation profile based on GPR images can be calibrated with manual snow-probing and firn-core drillings, the interpretations of the GPR images will be less uncertain (Sand and Bruland, 1998). GPR data can be used to improve accumulation maps and to check the representativeness of manual snow-probing and ice-core results. Accumulation is a function of precipitation, sublimation and net deposition/erosion of snow by drifting.

The distribution of accumulation over the ice cap appears to be influenced by ice-surface topography and meteorological factors. The lowest and highest accumulation sites occur on the north-northwestern and south-southeastern parts of the ice cap, respectively. The accumulation pattern reflects the asymmetrical ice divides separating the northern and western parts of the ice cap from the eastern and southern parts. Roughly the same pattern was mapped by Schytt (1964) during the 1957/58 winter. This snow-distribution pattern reflects the large-scale wind field caused by lowpressure areas passing across the Barents Sea, bringing moist air to the eastern parts of Svalbard. This circulation pattern is controlled by the position of the climatological low-pressure area near Iceland and the relatively high pressure over Greenland and the Arctic Ocean. Less frequently, moist air masses arrive with westerly and southerly winds (Førland and others, 1997a). Polar air masses from the northeast dominate during the winter period (Barrie, 1986).

Topographical factors affecting accumulation are elevation, exposure, steepness and aspect of the terrain slope. Precipitation related to orographic lifting of the moister air is an important process in the polar regions. Southerly and easterly winds will deposit snow rapidly after reaching Austfonna, when the air masses are lifted and cooled. However, 
Austfonna is situated in a precipitation shadow for moister air masses from the west. This explains the maximum accumulation on the windward side of the ice cap. The relatively high accumulation found along the leeward side of the ice divide is probably a spillover effect, transferring high-accumulation area to the leeward side by wind effects. This effect was also very distinct on Austre Brøggerbreen (Førland and others, 1997b).

In order to calculate typical altitudinal accumulation gradients at different transects, the winter precipitation values are expressed as ratios to the accumulation at base camp. The accumulation-altitude relationship for the southern part of Austfonna indicates both a precipitation decrease and increase, depending on the distance from the dome of the ice cap. The precipitation gradients range from $-4 \%$ per $100 \mathrm{~m}$ (southeast transect) to almost 3\% per $100 \mathrm{~m}$ for the south transect (elevation span 250-775 $\mathrm{m}$ a.s.l.). In the northern part there is a precipitation gradient increase of $10-15 \%$ per $100 \mathrm{~m}$ (elevation span 250-775 m a.s.l.). Different gradients should therefore be used for the northern and southern parts of the ice cap. We emphasize that the measured precipitation gradients may not be representative of winter precipitation trends for other years, but the winter snow distribution was similar for winters 1997/98, 1957/58 and 1956/57. For comparison, Førland and others (1997b) reported a gradient of precipitation with elevation of $20 \%$ per $100 \mathrm{~m}$ for the Ny-Ålesund area, whereas Hagen and Lefauconnier (1995) reported a gradient of $25 \%$ per $100 \mathrm{~m}$ for Brøggerbreen. A study of the snow distribution carried out on several Spitsbergen glaciers has shown that gradients vary greatly, ranging from 0.003 to $0.237 \mathrm{~m}$ w.e. per $100 \mathrm{~m}$ (Winther and others, 1998). As for Austfonna, most of these variations are due to the location of the ice cap in relation to direction of the moisture-bearing air masses. This implies that it could be difficult to obtain gradients with large spatial validity.

\subsection{MANMB}

The MANMB at the top of Austfonna is $0.5 \mathrm{~m}$ w.e. (mean value for 1963-97) and can be compared to and discussed in relation to earlier results. This is much higher than the value of 0.06-0.07 $\mathrm{m}$ w.e. reported by Ahlmann (1933). However, as mentioned by Schytt (1964), the low value reported by Ahlmann was due to difficulties in interpreting the stratigraphic method of determining accumulation, leading to incorrect estimates of the accumulation rates. From total beta radioactivity measurements, Punning and others (1986) reported a net mass balance of $0.81 \mathrm{~m}$ w.e. This high value was due to difficulties in interpreting the radioactivity profile, which included natural and artificial components. Zagorodnov and Arkhipov (1990) estimated this mass balance to be $0.3 \mathrm{~m}$ w.e. for recent centuries. K. Kamiyama and others (unpublished information) determined the 1963 layer by the tritium method, and their mass-balance determinations are in close agreement with our values.

\section{GONCLUSIONS}

Chernobyl fallout has been detected in 19 ice cores from the accumulation area of Austfonna. Radioisotopes from the atmosphere are mainly deposited on the ice surface by wet deposition (snowfall), as demonstrated with ${ }^{210} \mathrm{~Pb}$. Postdepositional processes due to wind scouring, melting and percolation, as demonstrated by the ${ }^{137} \mathrm{Cs}$ and ${ }^{210} \mathrm{~Pb}$ analysis, result in large spatial variations of the specific isotope concentrations.

Comparison of the Austfonna winter mass-balance results from GPR, manual snow probing and ice cores shows that the first significant reflection detected corresponds to the snow-firn (above the firn line) and snow-ice (below the firn line) interface. GPR could be used for winter snow surveys, but reliable measurements of the snow thickness are only obtained when GPR is calibrated with manual depth measurements. The radar results show marked spatial variations in accumulation rate over both short and long distances. The winter snow accumulation and the MANMB are higher on the southeastern than on the northwestern side of the ice cap, indicating that more winter accumulation comes with easterly than with westerly winds.

The results show large spatial variations in the MANMB rates (max. $0.54 \mathrm{~m}$ w.e.) even at a given altitude, as well as in the net mass-balance gradients $(0.059-0.151 \mathrm{~m}$ w.e. per $100 \mathrm{~m})$ and ELAs (124-467 $\mathrm{m}$ a.s.l.) across the ice cap.

The mean annual net mass budget of the Austfonna accumulation area is about $1 \mathrm{~km}^{3}$, as determined from five different isopleths (Table 4). This budget may be slightly underestimated due to the locations of some of the ice cores on ice divides rather than on flowlines. The AAR of Austfonna reaches 0.45 .

Our study from several Svalbard ice cores indicates that there is no trend in the accumulation rates over the periods 1963-86 and 1986-97/98.

The mean annual net balance gradients presented here can be used as input for models of the mass and energy balance of glaciers in the Arctic.

\section{AGKNOWLEDGEMENTS}

This study was financed by European Commission contract No. ENV4-CT97-0490 "The Response of Arctic Ice Masses to Climate Change" and supported by Université Joseph Fourier, Grenoble (BQR 1997/98) and by the University of Oslo. The 1998 and 1999 fieldwork on Austfonna was made possible by additional financial support from Institut Français de la Recherche et de la Technologie Polaires. Samples down to $40 \mathrm{~m}$ were collected from the deep ice cores retrieved by our Japanese colleagues from NIPR. The logistics support by the NPI was greatly appreciated. M. Sund and L. Karlöf participated in the logistics and in ice-core drilling and stratigraphy work. The comments from J. A. Dowdeswell, M. R. van den Broeke and R. van de Wal were greatly appreciated, and improved this paper in many ways.

\section{REFERENGES}

Ahlmann, H.W:son. 1933. The inland cartography of North-East Land. Geogr. Ann., 15(1), 47-68.

Barrie, L. A. 1986. Arctic air pollution: an overview of current knowledge. Atmos. Environ., 20(4), 643-663.

Binney, F. G. 1925. The Oxford University Arctic Expedition 1924. Geogr. J., 66(1), 9-40.

Delmas, R. and M. Pourchet. 1977. Utilisation de filtres échangeurs d'ions pour l'étude de l'activité $\beta$ globale d'un carottage glaciologique. International Association of Hydrological Sciences Publication 118 (Symposium at Grenoble 1975 - Isotopes and Impurities in Snow and Ice), 159-163.

Dowdeswell, J. A. 1986. Drainage-basin characteristics of Nordaustlandet ice caps, Svalbard. 7. Glaciol., 32(110), 31-38.

Dowdeswell, J. A. and A. P. R. Cooper. 1986. Digital mapping in Polar regions from Landsat photographic products: a case study. Ann. Glaciol., 8, 47-50.

Dowdeswell, J. A. and D. J. Drewry. 1989. The dynamics of Austfonna, Nordaustlandet, Svalbard: surface velocities, mass balance, and subglacial melt water. Ann. Glaciol., 12, 37-45. 
Dowdeswell, J. A., D. J. Drewry, A. P. R. Cooper, M. R. Gorman, O. Liestøl and O. Orheim. 1986. Digital mapping of the Nordaustlandet ice caps from airborne geophysical investigations. Ann. Glaciol., 8, 51-58.

Eiken, T., J. O. Hagen and K. Melvold. 1997. Kinematic GPS survey of geometry changes on Svalbard glaciers. Ann. Glaciol., 24, 157-163.

Fleming, K. M., J. A. Dowdeswell and J. Oerlemans. 1997. Modelling the mass balance of northwest Spitsbergen glaciers and responses to climate change. Ann. Glaciol., 24, 203-210.

Førland, E. J., I. Hanssen-Bauer and P. Ø. Nordli. 1997a. Climate statistics and longterm series of temperatures and precipitation at Svalbard and Jan Mayen. Oslo, Det Norske Meteorologiske Institutt. (DNMI Klima Report 21/97.)

Førland, E. J., I. Hanssen-Bauer and P. Ø. Nordli. 1997b. Orographic precipitation at the glacier Austra Broggerbreen, Svalbard. Oslo, Det Norske Meteorologiske Institutt. (DNMI Klima Report 02/97.)

Harrison, C. H. 1973. Radio echo sounding of horizontal layers in ice. $\mathcal{F}$. Glaciol., 12(66), 383-397.

Jonsson, S. 1982. On the present glaciation of Storöya, Svalbard. Geogr. Ann., 64A $(1-2), 53-79$

Kovacs, A., A. J. Gow and R. M. Morey. 1995. The in-situ dielectric constant of polar firn revisited. Cold Reg. Sci. Technol., 23(3), 245-256.

Lefauconnier, B., J. O. Hagen, J. F. Pinglot and M. Pourchet. 1994. Mass-balance estimates on the glacier complex Kongsvegen and Sveabreen, Spitsbergen, Svalbard, using radioactive layers. 7. Glaciol., 40(135), 368-376.

Melvold, K., J. O. Hagen, T. Eiken and J. F. Pinglot. 1999. Report from fieldwork on the Austfonna ice cap, Svalbard, 7th April-7th May 1999. Oslo, University of Oslo. Department of Physical Geography. (Second year report of E.C. contract No. ENV4-CT97-0490.)

Pinglot, J. F. and M. Pourchet. 1994. Spectrométrie gamma à très bas niveau avec anti-Compton $\mathrm{NaI}(\mathrm{Tl})$, pour l'étude des glaciers et des sédiments. CEA (Commissariat à l'Énergie Atomique) Note 2756, 291-296.

Pinglot, J. F. and 8 others. 1994. Natural and artificial radioactivity in the Svalbard glaciers. 7. Environ. Radioactivity, 25(1), 161-176.

Pinglot, J. F., M. Pourchet, B. Lefauconnier and M. Creseveur. 1997. Equilibrium line and mean annual mass balance of Finsterwalderbreen, Spitsbergen, determined by in situ and laboratory gamma-ray measurements of nuclear test deposits. Ann. Glaciol., 24, 54-59.
Pinglot, J. F. and 6 others. 1999. Investigations of temporal change of the accumulation in Svalbard glaciers deduced from nuclear tests and Chernobyl reference layers. Polar Res., 18(2), 315-321.

Pourchet, M., J. F. Pinglot and J. C. Gascard. 1986. Accumulation in Svalbard glaciers deduced from ice cores with nuclear tests and Chernobyl reference layers. Nature, 323, 676.

Preiss, N., M.-A. Mélières and M. Pourchet. 1996. A compilation of data on lead 210 concentration in surface air and fluxes at the air-surface and water-sediment interfaces. 7. Geophys. Res., 101 (D22), 28,847-28,862.

Punning, Ya.-M. K., T. A. Martma, K. E. Tyugu, R. A. Vaykmyae, M. Pourchet and F. Pinglot. 1986. Stratification in an ice core from Vestfonna, Nordaustlandet. Polar Geogr. Geol., 10(1), 39-43. (Translated from Mater. Glyatsiol. Issled. 52, 1985, 202-205.

Retzlaff, R., N. Lord and C. R. Bentley. 1993. Airborne-radar studies: Ice Streams A, B and C, West Antarctica. F. Glaciol., 39(133), 495-506.

Rosenberger, A., H. Oerter and H. Miller. 1997. Short range radar observations on Ekströmisen, Antarctica. Polarforschung, 65(1), 1995, 1-14.

Sand, K. and O. Bruland. 1998. Application of georadar for snow cover surveying. Nord. Hydrol., 29(4-5), 361-370.

Schytt, V. 1964. Scientific results of the Swedish Glaciological Expedition to Nordaustlandet, Spitsbergen, 1957 and 1958. Geogr. Ann., 46(3), 243-281.

Schytt, V. 1969. Some comments on glacier surges in eastern Svalbard. Can. 7. Earth Sci., 6(4), Part 2, 867-873.

Ulaby, F. T., R. K. Moore and A. K. Fung. 1986. Microwave remote sensing, active and passive. Vol. 3. From theory to applications. Reading, MA, AddisonWesley Publishing Co.

Watanabe, O., K. Kamiyama, T. Kameda, S. Takahashi and E. Isaksson. 2000. Activities of the Japanese Arctic Glaciological Expedition in 1998 (JAGE 1998). Bull. Glaciol. Res. 17, 31-35.

Winther, J.-G., O. Bruland, K. Sand, Å. Killingtveit and D. Marechal. 1998. Snow accumulation distribution on Spitsbergen, Svalbard, in 1997. Polar Res., 17 (2), 155-164.

Zagorodnov, V. and S. Arkhipov. 1990. Studies of structure, composition and temperature regime of sheet glaciers of Svalbard and Severnaya Zemlya: methods and outcomes. Bull. Glacier Res. 8, 19-28.

MS received 2 January 2001 and accepted in revised form 15 August 2001 